\title{
Dignity and Humiliation: Identity Formation among Syrian Refugees
}

\author{
Basileus Zeno \\ University of Massachusetts, Amherst \\ basileus.zeno@gmail.com
}

\begin{abstract}
Since 2011 half of Syria's population has been forced to flee its homes. Much research has focused on the macro-level challenges and post-conflict reconstruction plans. In this article, I focus on the micro-level by examining the dialectic of "humiliation" and "dignity" as a dynamic that shapes and transforms Syrian refugees' identities through sustained interaction, and sometimes through struggle, with others, who can be proregime or pro-opposition Syrians, or pro-refugees or anti-refugees in hosting countries. Methodologically, I use an interpretive approach which focuses on context-specific meanings and their relation to power, seeking multifaceted understandings of refugees' lived-experience. This research is based on ethnographic fieldwork and ordinary language interviews conducted in the United States, and semi-structured, open-ended interviews with Syrians in Germany and Turkey. I show that researching participants' meaning-making in their own settings reveals the dynamics of humiliation and dignity as dialectically interwoven in specific situational contexts and shaped by refugees' lived-experience in both the country of origin (in the past) and the hosting country (in the present).
\end{abstract}

\section{Keywords}

Arab Spring - Syrian refugees - humiliation - dignity - interpretivism

* The author would like to thank Marc Lynch, Laurie Brand, and the participants in the POMEPS workshop on Refugees and Migration Movements in the Middle East, Timothy Pachirat, Ben Nolan, and Katty Alhayek for their thoughtful feedback and comments on multiple drafts of this article. Thanks also to Catholic Charities, Smith College School for Social Work and the Building Together Planning Committee, Vijay Prashad, and Susannah Crolius for their support during the research process. Lastly, a special thanks to all refugees and asylees who have graciously allowed me into their lives and shared their stories and experiences with me. 
The 2011 uprising and subsequent war has radically changed Syrians' perception of national identity. The country became de facto divided among different groups, each with their own vision of Syria's future and their own repertoire of symbols and practices of inclusion and exclusion. Thousands of non-Syrian jihadists, many fighting under the banner of the self-proclaimed "Islamic State" (also known as ISIS), have succeeded in controlling large swaths of Syria and Iraq. Sectarian tensions among different segments of Syrian society have intensified with the increasing intervention of regional and global powers. Generations of Syrians were born in exile and have no memories of pre-uprising-cum-conflict Syria. Others were forced to leave their destroyed cities and villages with no more than their clothes and fled to Syria's neighboring countries, ${ }^{1}$ or to more distant refuge such as Sudan ${ }^{2}$ or Europe. Affected families and individuals of lower-in-socioeconomic status could not afford the risky and expensive trip, leaving only the option of finding shelter in regimeheld areas. In every case, displaced Syrians must reckon with dynamics of identity-formation among pro-state or pro-regime on the one hand, and the pro-opposition and the intra-conflict in each party on the other. Making sense of this requires more sensitivity to the methodological challenges of studying the impact of war and displacement on everyday people.

The most dramatic change has been the physical dislocation of the population. ${ }^{3}$ By the end of 2015, an estimated 11.5 percent of the population of

1 Borders have a filtering function which may limit or increase the possibility for trans-border transactions. The implementation of the new 2015 border policy relegated many Syrians, who were physically located within Lebanese territory and society, to a "liminal space" because they found themselves "outside" Lebanon as they were unable to leave or to renew their residency permits and thus have been excluded from legal status. Filippo Dionigi, "Rethinking borders: The dynamics of Syrian displacement to Lebanon," Middle East Law and Governance 9, no. 3 (2017): pp. 232-248.

2 After the imposition of new visa terms on Syrians by both the Lebanese and Turkish governments (January 2015 and January 2016 respectively), thousands of Syrians, many of whom are young men seeking to avoid being drafted, fled to Sudan, one of the few remaining countries that doesn't require a visa for entry. (Personal communications with a young Syrian dodger who fled to Khartoum through Lebanon on May 2017. Phone, July 12, 2017). According to the Government of Sudan's Commission of Refugees (COR), it is estimated that about 100,000 Syrians have arrived in Sudan since 2011. See: The United Nations Office for the Coordination of Humanitarian Affairs (OCHA), "Humanitarian Bulletin Sudan," Issue 40, September 26-October 2, 2016: 2.

3 Syrian displacement to neighboring countries increased dramatically in late 2012 and 2013 with the militarization of the uprising and the struggle for territorial control. This transformed the nature of activism among Syrians in Jordan from a grassroots response to the uprising into an "aid-based response to a humanitarian crisis." Rana Khoury, "Activism among Syrian Refugees in Jordan," Middle East Law and Governance 9, no. 3 (2017): pp. 267-281. 
Syria (pre-war, 23 million) were killed or injured due to armed-conflict. More than 4.8 million Syrians have fled the country, and rough estimates show that over 7.6 million Syrians are now internally displaced persons (IDPs) within the country. ${ }^{4}$ More than 80 percent of the Syrian population is living below the poverty line. In terms of education, the "national ratio of enrolment in primary education fell from 98 percent in 2010 to 70 percent in 2013 and further to 61.5 per cent in 2015."

These numbers foretell a grim future. Much research has focused on the macro-level challenges which make any post-conflict reconstruction plans seem implausible in the short-run. This article focuses instead on the microlevel. The lived experience of refugees, asylum grantees, pending asylees, and IDPs vary dramatically from one place to another based on where they are located. ${ }^{6}$ In many cases they have been displaced several times, which further complicates any planning to reweave anything that could be seriously described as a Syrian social fabric.

Coverage of the "Syrian Refugee Crisis" tends to overshadow other crises and conflicts in the global south. It should, instead, be understood in terms of the larger context of these crises and conflicts. The number of forcibly displaced people in the world, as of 2016, exceeds 65.6 million individuals. In 1997, that number was only 33.9 million. ${ }^{7}$ While large-n statistical works and reports published by NGOs, hosting states, and international organizations such as the UNHCR (United Nations High Commissioner for Refugees), are crucial to underscore the urgency to address the global refugee crisis, I argue that any serious effort to address any part of the ballooning population of forcibly displaced

4 The Syrian Center for Policy Research (SCPR), Confronting fragmentation, impact of Syrian crisis report. February, 2015: 8. http://scpr-syria.org/publications/policy-reports/ confronting-fragmentation/.

5 United Nations Economic and Social Commission for Western Asia (escWA), Syria at War: Five Years On, 2016, https://www.unescwa.org/publications/syria-war-five-years.

6 In response to the influx of refugees, states changed their policies which have had a direct and negative impact on Syrian refugees. Asylees and refugees are vulnerable to political instrumentalization and politicians might change their positions. For example, Lama Mourad shows how the mobilization of thousands of Syrians in Beirut in favour of President Bashar Assad during the Syrian Presidential Elections of May 2014 transformed the image of Syrian refugees in the eyes of Lebanese politicians (especially March 14 leaders) from being perceived as safe political tools to potential threats. Consequently, a few months later, the Council of Ministers adopted the "October Policy," which aimed to reduce the number of displaced Syrians and changed the pre-existing border entry regulations. For more detail, see Lama Mourad, "Inaction as policy-making: Understanding Lebanon's early response to the refugee influx," Middle East Law and Governance 9, no. 3 (2017): pp. 249-266.

7 UNHCR, Global Trends: Forced Displacement in 2016, June 19, 2017, http://www.unhcr.org/ globaltrends2016/. 
people should take into consideration the meaning-making practices of the people concerned as these practices have developed through displaced people's particular experiences and conditions of displacement.

Lumping diverse groups of people with their different experiences, backgrounds, classes, and cultures under the homogenizing category of "migrant" or "refugee" render their lived experiences invisible. Top-down programs that do not incorporate the voices and experiences of refugees and asylees doubleinvisibilize them. ${ }^{8}$ Not only is this profoundly alienating for refugees and asylees themselves, these program designs are self-defeating more generally, often intensifying resentments between host and hosted populations.

"Humiliation" and "dignity" are crucial aspects of the lived experience of Syrian refugees. Scholars and practitioners, including psychologists, paid little attention to the role of humiliation and dignity in the processes of identityformation among refugees, many of whom are survivals of traumatized experience. One possible reason for this lack of attention may be lies in the rapid transformation of the initial state of humiliation, caused by a direct experience, into emotions. Many traumatized refugees swing between two poles of humiliation: feeling sadness and despair for the loss of hope, beloved ones, places on one side; and anger and need for revenge on the other. ${ }^{9}$ The destructive force of humiliation, if ignored, can last for years independently of its original cause. I understand the dialectic of "humiliation" and "dignity"10 as a dynamic that shapes and transforms Syrian refugees' identities through sustained interaction, and sometimes through struggle, with others, who can be pro-regime or pro-opposition Syrians, or pro-refugees or anti-refugees in hosting countries. Methodologically, I use an interpretive approach which focuses

8 For instance, Katty Alhayek (2014) criticizes how feminist online campaigns that aimed and claimed to represent Syrian refugee women in Jordan were disconnected from the offline realities on the ground and lived experience of refugee women. Katty Alhayek, "Double Marginalization: The Invisibility of Syrian Refugee Women's Perspectives in Mainstream Online Activism and Global Media," Feminist Media Studies, 14, no. 4 (2014): 696-70o.

9 Richard F. Mollica. Healing Invisible Wounds: Paths to hope and recovery in a violent world. (Nashville: Vanderbilt University Press, 2006, 79-81, 122).

10 Taylor refers to the modern concept of dignity as a notion "used in a universalist and egalitarian sense" in contrast to the hierarchical concept of "honor" in the ancien régime sense. However, while the old system of hierarchical honor, in which honor was a matter of "préférences," was replaced with a rhetorical equality, the actual power relations and the system of "préférences" based in race, gender, and citizenship are just other manifestations. Charles Taylor, "The Politics of Recognition," in Multiculturalism: Examining the Politics of Recognition, ed. Amy Gutmann, (New Jersey: Princeton University Press, 1994), 25-73. 
on context-specific meanings and their relation to power, seeking multifaceted understandings of human experience rather than seeking to derive generalized predictive laws. ${ }^{11}$ This research is based on ethnographic fieldwork and ordinary language interviews ${ }^{12}$ conducted in the United States, and semistructured, open-ended interviews with Syrians in Germany and Turkey. ${ }^{13}$ There is an increasing number of political scientists, especially in the field of comparative politics, who ground their fieldwork and analyses in an "ethnographic sensibility" which requires a commitment to immersion in the field of research and the social life of the people under study. ${ }^{14}$ This ethnographicinterpretive approach is attentive to "empathetic understanding" of the participants' meanings and actions and the "ethics of power."15

Speaking from my own experience as a Syrian in exile and as a social scientist, any attempt to study the processes of identity-formation among Syrians post-2011 and of how refugees themselves understand their displacement

11 Peregrine Schwartz-Shea, "Judging Quality: Evaluative Criteria and Epistemic Communities," in Interpretation and Method: Empirical Research Methods and the Interpretive Turn, 2nd ed. ed. Dvora Yanow and Peregrine Schwartz-Shea (Armonk, N.Y: M.E. Sharp, Inc, 2014), 120-146.

12 Schaffer defines ordinary language as "a tool for uncovering the meaning of words in everyday talk." Frederic Charles Schaffer, "Ordinary language interviewing," in Interpretation and Method: Empirical Research Methods and the Interpretive Turn, and ed. ed. Dvora Yanow and Peregrine Schwartz-Shea (Armonk, N.Y: M.E. Sharp, Inc, 2014), 184.

13 Due to the restriction on my travel as a Syrian researcher and pending asylee (since 2013), I wasn't able to travel to Turkey and Germany to conduct ethnographic fieldworks and I had to depend on interviews via Skype with my participants in both countries, which, in itself, is an indicator of methodological challenges that confront Syrian researchers.

14 Ellen Pader, "Seeing with an ethnographic sensibility: Explorations beneath the surface of public policies," in Interpretation and Method: Empirical Research Methods and the Interpretive Turn, and ed. ed. Dvora Yanow and Peregrine Schwartz-Shea (Armonk, N.Y: M.E. Sharp, Inc, 2014), 194-208. Edward Schatz, "Introduction: Ethnographic Immersion and the Study of Politics," in Political Ethnography: What Immersion Contributes to the Study of Power, ed. Edward Schatz (Chicago: University of Chicago Press 2009), 1-22. Lisa Wedeen, "Reflections on ethnographic work in political science." Annual Review of Political Science 13: (2010): 255-272. Erica S. Simmons, and Nicholas Rush Smith. "Comparison with an Ethnographic Sensibility." Ps: Political Science and Politics 50, no. 1 (2017): 126-30. Wendy Pearlman, Puzzles, Time, and Ethnographic Sensibilities: Research Methods after the Arab Spring, Middle East Law and Governance 7 (2015): 132-140.

15 Timothy Pachirat. Every twelve seconds: Industrialized slaughter and the politics of sight. (New Haven: Yale University Press, 2011), 284; Yanow, Dvora. "Thinking Interpretively: Philosophical Presuppositions and the Human Sciences," in Interpretation and Method: Empirical Research Methods and the Interpretive Turn, and ed. ed. Dvora Yanow and Peregrine Schwartz-Shea (Armonk, N.Y: M.E. Sharp, Inc, 2014), 23. 
risks compounding the tremendous semantic violence refugees experience. To minimize this risk, it is imperative that these processes be approached in a manner that is attuned to the lived-experience of Syrians before and after the uprising, the web of meanings Syrians have themselves constructed through Syria's contemporary history.

\section{The Dialectical Relationship between Humiliation and Dignity}

In December 2010, the Arab world was about to witness a series of massive, contagious social movements which would sweep across Egypt, Libya, Yemen, Bahrain, Iraq, Morocco, Syria and other Arab countries, toppling, albeit in different ways, authoritarian leaders including Zine El Abidine Bin Ali in Tunisia, Hosni Mubarak in Egypt, Ali Abdullah Saleh in Yemen, and Muammar alQaddafi in Libya. In almost all cases, the initial waves of peaceful protest were confronted by lethal attacks and suppression by oppressive regimes, and, in Libya, Yemen and Syria, turned into armed confrontation and eventually proxy wars leading to unprecedented waves of refugees.

On March 15, 2011, a group of young activists organized a demonstration in Damascus, chanting, "God, Syria, Freedom and that's enough/ Allah, Souriya, Houriya w Bas," a slogan that defied the Baathist slogan: "God, Syria, Bashar and that's enough/ Allah, Souriya, Bashar w Bas." Many Syrian activists consider that moment to mark the birth of the "Syrian Revolution." Others mark the birthdate three days later, when the first activists - since known as "martyrs of the revolution" - died in southern Syria during the protest of "Jum'at al-Karama/ Friday of Dignity"16 When interviewed in August 2014, one young activist who attended the March 15 protest distinguished between the two dates as follows: "The protest of Souq al-Hamidiyeh [March 15] was organized by activists who were inspired by the Arab Spring, whereas the protests in Dar'a [March 18] were more spontaneous and led by ordinary people who wanted their children to be released immediately from Assad's prison."

16 Based on meetings and discussions with activists in Damascus on March and April 2011. It should be noted that both Syrian and Yemeni protesters shared the same slogan of that day. "Friday of Dignity" also ended in a massacre in San'a, when pro- Saleh's regime gunmen killed at least 45 protesters and wounded 200 civilians. Human Rights Watch (HRW). Unpunished Massacre: Yemen's Failed Response to the "Friday of Dignity" Killings. February 12, 2013. https://www.hrw.org/sites/default/files/reports/yemeno213webwcover_o.pdf.

The call for "dignity" was ubiquitous in the Middle East throughout the 2011. See Wendy Pearlman, "Moral Identity and Protest Cascades in Syria," British Journal of Political Science (2016): 1-25. 
These protests followed a series of protests by Syrians in solidarity with the Libyan and the Egyptian people. A month earlier, on February 17, 2011, an unexpected incident happened in Damascus: a police officer brutally assaulted the son of a shop owner in the Souq al-Hariqa market. Within minutes, hundreds of Syrians gathered to protest against the security forces and shouted together, "Thieves Thieves/Haramieh Haramieh" and "The Syrian people will not be humiliated/al-Sha'ab al-Souri ma Biiynthal," a slogan that would become popular later. ${ }^{17}$ The minister of the interior halted the protest by promising the offending officer would be punished. Nevertheless, within hours, the video of the demonstration went viral on YouTube and Facebook.

This slogan - "The Syrian people will not be humiliated" - has multiple layers of significance. Unlike the soon-to-be more organized slogans and coordinated efforts between activists and political actors - i.e. actors who were members of political parties and ex-political prisoners who resisted the regime of both Assads - this slogan was an expression of semiotic resistance, re-appropriating the Assads' regime's own discourse of resistance and anti-imperialism which it had used for the purposes of self-legitimation. Prior to the Souq al-Hariqa's protests and following the Tunisian and the Egyptian revolutions, President Bashar al-Assad confidently asserted in an interview with The Wall Street Journal on January 31, 2011, that Syria was different:

We have more difficult circumstances than most of the Arab countries but in spite of that Syria is stable. Why? Because you have to be very closely linked to the beliefs of the people. This is the core issue. When there is divergence between your policy and the people's beliefs and interests, you will have this vacuum that creates disturbance. So people do not only live on interests; they also live on beliefs, especially in very ideological areas. ${ }^{18}$

Thus, this slogan was at the same time a spontaneous "reaction" of everyday people to the humiliating treatment of a member of their neighborhood at the hand of a policeman on the one hand, and an "action" that transcended the immediacy of the incident to reclaim dignity for all Syrians on the other. The protest took place in public, in the Syrian capital, during the "Arab Spring,"

17 The video of the protest of Souq al-Hariqa is available on the following link: MisbarSyria, The Syrian Protest of Rage in Damascus-February 17, 2011, YouTube, February 17, 2011. Accessed September 16, 2017. https://www.youtube.com/watch?v=qDHLsU-ik_Y\&feature =related.

18 Bashar Asad, "Interview With Syrian President Bashar al-Assad," The Wall Street Journal, January 31, 2011, http://online.wsj.com/article/SB1000142405274870383320457611471244112 2894.html. 
and defied more than four decades of fear cultivated by Hafiz al-Assad and his successor and son Bashar. ${ }^{19}$ It was a denunciation of the daily encounters of intimidation and humiliation with the security forces or civilians with connections (wasta).

Many of my interviewees described the category of "refugee" as a "humiliating" designation, and activists/refugees in particular frequently cited that slogan as an expression of the primary motive to protest against the Syrian regime. As Reem, an activist/pending asylee in the United States, puts it:

...the protest of al-Hariqa was like a scream inside the heart of every Syrian who lived in fear and had been humiliated by the mukhabarat [security forces] for decades under both Assads. I wasn't there but when I watched the video on YouTube and heard the people chanting The Syrian People will not be Humiliated, I felt wow! I am a human being and I am proud to be Syrian. Don't forget the timing as we were already inspired by Bouazizi. ${ }^{20}$

But now we are back to square one, humiliated in our country and humiliated outside it. ${ }^{21}$

When I asked another activist, Yasmeen, working with a non-violent movement based in Gaziantep, Turkey, "What does it mean for you to be a Syrian?" she remained silent for a while before answering:

Well ... I do not really know. It is a difficult question. You know I feel guilty and ashamed of being Syrian nowadays. The country has been destroyed after the revolution. I will tell you a personal example. I was lost the other day in Gaziantep. I asked a Turkish officer at the metro station about directions. He asked me about my nationality. I kept silent! I ignored his question because I thought I would be stigmatized by him if he knew I am Syrian. ${ }^{22}$

Yasmeen and her sister have been refugees in Germany since June 2015. When I asked her about her new experience, she said:

\footnotetext{
19 Wendy Pearlman, "Narratives of fear in Syria," Perspectives on Politics 14, no. 1 (2016): 21-37.

20 Mohamed Bouazizi, was a Tunisian college-educated street cart vendor, whose selfimmolation in December 2010 (three months before the Syrian Uprising) sparked the wave of Arab protests.

21 Interview with Reem, Washington D.C, USA, August 8, 2014.

22 Skype interview with Yasmeen when she was in Gaziantep, southern Turkey, on September 2, 2015.
} 
I didn't like Gaziantep because it was a conservative city in general, but I loved Istanbul. It's my favorite city, but at the time Syrians didn't have a clear legal status ... I needed documents, I mean a non-Syrian passport because I couldn't travel or do anything, this is why I decided to register at the UN HCR center on January 2014[...] Here, I have health insurance, I am learning the language but I hate the word refugee in German, it provokes me ... why do you insist in reminding me that I am a refugee?... You don't feel they treat you as equal and they look down on you. ${ }^{23}$

Similarly, Suleiman, a refugee who was resettled with his family in Massachusetts, doesn't feel comfortable when he hears the word refugee:

No one wants to be a refugee. I even hate the word refugee or the fact that my children are refugees and that I had to flee from my country because we have someone who is killing the people and no one is stopping him! If you want to solve the refugee crisis, don't give me bread - stop the fire in my farm. ${ }^{24}$

This sense of humiliation and the negative connotation that some refugees attributed to the category of refugee shouldn't, however, be reduced to a passive feeling or a 'generalizable' permanent characteristic of the experience of being a refugee. In fact, several interviewees treated humiliation dialectally by demonstrating pride in what they stood for - especially activists who frequently referred to the Syrian uprising as Thawrat al-Karama (the Revolution of Dignity); or in who they are by referring to Syria's ancient history; or the hospitality of many Syrians towards other refugees in the past. While Suleiman, whom I quoted above, hates the category of refugee, he substituted it for another word in Arabic: daif (guest). This linguistic shift reflects his personal experience at the individual level, and the Syrian experience at the state level, with other refugees (Palestinian, Iraqis, and Lebanese) who fled the wars and came to Syria. According to Suleiman:

We are not refugees, we are guests. We came to America and America opened its heart to us and supported us, we want to be here positive [actors] for America[...]I want to work and do good things and to be integrated in the American society, and to transfer our Arabic civilization to the U.S. ${ }^{25}$

23 Skype interview with Yasmeen, Augsburg, Germany, on January 22, 2016.

24 Participant observation in West Springfield, MA, USA, on October 6, 2016.

25 Participant observation in West Springfield, MA, USA, on October 6, 2016. 
In contrast to what the category of refugee implies (finding a new permanent home), daif signifies a feeling of temporality, expressing the desire among many Syrian refugees to believe that their time in exile is limited and once the war ends they will return "home." Even though Suleiman and other refugees believe, or want to believe, that their presence in their relocation countries is temporary, they reject the dominant representation of refugees as passive or helpless actors who are dependent on others. Rather, even with the rising frenetic obsession with ISIs, they believe that their cultures are valuable and misunderstood in the West, and that they can be active and positive contributors to society when they are given the chance.

Conversely, other refugees reflected on their previous whole life in Syria and insisted that the us is their real "home" because "for the first time ever I feel I am a respected human being with rights and dignity" as Ismail, a young man in his late 20 from Damascus, told me. ${ }^{26}$ Ismail came to the us as a graduate student in 2014, but he dropped out of his program because he couldn't afford the tuition fees and the living expenses:

I thought my affluent uncles would help me, but they didn't! They are American citizens and outspoken figures in their support for the Syrian revolution and Syrian refugees in Jordan, what hypocrites! They almost kicked me out of the house for no reason. I ended up homeless for days sleeping on benches in public parks until one of the charity organizations helped me out and found me a place with a family. I applied for asylum on October 2014, but a few months later, maybe January 2015, they [the USCIS] announced an extension of the TPS [Temporary Protected Status] for Syria, so I applied, and this is how I got my Social Security number and my work permit. After waiting for two years, I had my interview, which lasted for one hour, and I received the final decision three weeks later. I have to tell you that with all difficulties and challenges that I faced here in the us, you know one helps no one and you have to be by your own, but this my home now. Syria only reminds me of all types of humiliation and repression in every spot and even before the revolution ... at school, in college, in the army, even when you pay your bills, you will be reminded that you are nobody!

There is a stark difference (heavily correlated with class) between refugees who consider themselves as guests who "intend" to come back to their "permanent home" when the war ends, and refugees, and asylees, who are 
constructing a sense of place and working to find a new home in hosting countries. This difference often cuts across families and communities, adding still more complexity to the already highly complex processes of identity formation people in exile must undergo. Researching participants' meaning-making in their own settings reveals the dynamics of humiliation and dignity as dialectically interwoven in specific situational contexts and shaped by refugees' lived-experience in both the country of origin (in the past) and the hosting country (in the present).

\section{The Visible "Other"}

The massive populations of Syrian refugees in Syria's neighboring countries were effectively invisible in the Western media between 2011 and 2014. This reflects Hannah Arendt's observation that "the more the number of rightless people increased, the greater became the temptation to pay less attention to the deeds of the persecuting governments than to the status of the persecuted."27 Comparing to Syria's neighboring countries, only slightly more than 10 percent of the total number of registered Syrian refugees sought asylum in Europe - yet the visibility of the "Syrian Refugee Crisis" as experienced by Western countries was exaggerated ${ }^{28}$ in media and political platforms, including the 2016 U.s. presidential campaign. ${ }^{29}$ Attention from European and American politicians, policy-makers and NGOs increased significantly after the images of the lifeless body of three-year-old Syrian boy, Aylan Kurdi, made global headlines after he drowned on September 2, 2015. These images galvanized public attention to a grim crisis and motivated several humanitarian organizations, aid charities and individuals to volunteer to support the new Mediterranean Sea arrivals to the Greek islands. ${ }^{30}$

27 Hannah Arendt, The Origins of Totalitarianism. $3^{\text {rd }}$ ed. (London: George Allen \& Unwin, 1967), 294 .

28 The violence leading to displacement should lead one to question the very terms "Syrian Refugee Crisis" and "European Refugee Crisis." See Rawan Arar, "The New Grand Compromise: How Syrian Refugees Changed the Stakes in the Global Refugee Assistance Regime," Middle East Law and Governance 9, no. 3 (2017): pp. 298-312.

29 Europe: Syrian Asylum Applications From Apr 2011 to Feb 2016 (EU+Countries Including Norway and Switzerland), Reliefweb, February 11, 2016, http://reliefweb.int/report/world/ europe-syrian-asylum-applications-apr-2011-feb-2016-eu-countries-including-norway -and.

30 According to the United Nations High Commissioner for Refugees, the top eight nationalities of the over one million Mediterranean Sea arrivals between January 2015 and March 
Many activists and organizations appealed to the "sense of humanity" and mobilized the imagined human community to help the powerless and poor "other." Refugees, asylees, and migrants are categories that designate homogenized groups that are represented as territorially and culturally uprooted. Ethnographer Liisa Malkki aptly criticizes such categorical mystification that rests on old essentialist and reductionist Eurocentric practices:

The universalism of the "Family of Man" depoliticizes fundamental inequalities and injustices in the same manner that the homogenizing, humanitarian images of refugees work to obscure their actual sociopolitical circumstance erasing the specific, historical, local politics of particular refugees, and retreating instead to the depoliticizing, dehistoricizing register of a more abstract and universal suffering. ${ }^{31}$

The media attention typically spoke generically about Syrian refugees, but in fact conflated refugees and migrants, and barely mentioned other nationalities or the larger numbers of refugees in non-European countries. ${ }^{32}$ The representation of Syrian refugees, after the photo of Aylan went viral, focused on women and children as helpless, passive, and voiceless victims of violence and brutality. Despite liberal pride in the abstract universality of human rights, and the increasingly interconnected and globalized world, the perception of "human" and "culture" are highly territorialized and still rooted the nationstate order. ${ }^{33}$ In his recent book on the refugee crisis, Slavoj Žižek argues that refugees believe in the European Union's principle of "freedom of movement" which they take too seriously. This right is only guaranteed for the citizens of the EU's members and doesn't extend to all people. He justly calls this system a

2016 were Syrian Syria Arab Republic (46.7\%), Afghanistan (20.9\%), Iraq (9.4\%), Eritrea (3.4\%), Pakistan (2.5\%), Iran (2.3), Nigeria (2.2\%), Somalia (1.2\%). UNHCR, September 20 , 2016, http://data.unhcr.org/mediterranean/documents.php?page=1\&view=grid\&Type $\% 5$ $\mathrm{B} \% 5 \mathrm{D}=3$ \& Search=\%23monthly\%23.

31 Liisa H. Malkki, Purity and Exile: Violence, Memory, and National Cosmology among Hutu Refugees in Tanzania. (Chicago: University of Chicago Press,1995), 13.

32 According to the UNHCR, "nearly 20 people are forcibly displaced every minute as a result of conflict or persecution." Figures at a Glance, UNHCR, June 25, 2017, http://www.unhcr .org/en-us/figures-at-a-glance.html.

33 Fanon challenges claims of universal values arguing that "[ $t$ hose values which seemed to ennoble the soul prove worthless because they have nothing in common with the real-life struggle in which the people are engaged." Frantz Fanon, The Wretched of the Earth, trans. Richard Philcox (New York: Grove, 2004), 11. (My thanks to Ben Nolan for a productive discussion on Fanon). 
new form of apartheid where "commodities circulate freely, but not people." 34 Yet, Žižek reduces his analysis of the challenges facing European governments, especially German, in their efforts to integrate refugees socially and culturally to what seems an irresoluble problem: "how many of them really want to be integrated?"35 In fact, contrary to Žižek's concerns which are also shared by many Germans and Europeans, Syrians who have been resettled in Germany since 2015 are less obsessed with cultural differences. As Wendy Pearlman observes during her field research in Germany, the most significant source of anxiety for many Syrian refugees and asylum seekers is governmental bureaucracy, which shapes their everyday concerns and, in some cases, imposes obstacles that prevent them from regaining a sense of normalcy. ${ }^{36}$

Ethnography offers the only non-speculative avenue by which to approach answering such a question. Interpretivist ethnographers would try to "understand" and analyze meaning-making practices from below by immersing themselves in the lives and context where refugees live. Not only they interrogate presuppositions of fixed "cultural differences," and reified categories and classifications such as "Muslims" and "Americans" and "Europeans," or "Arabs" "Kurds" and "Jews," or "Islamic culture" and "Arab culture," but also they treat culture as "semiotic practices" and provide rich and complex understanding of the social and political life. ${ }^{37}$

The instantaneous discursive shift "against" refugees, and Syrians in particular, following the November 2015 attacks in Paris, represents a "momentary disturbance," but not to the normal everyday life and to Western culture as Žižek claims, ${ }^{38}$ but rather it showcases how the anti-refugee stance is arguably

34 Slavoj Žižek. Against the Double Blackmail: Refugees, Terror and Other Troubles with the Neighbours (UK: Penguin, 2016), 54. Žižek's inquiry seems, at first glance, to be concerned with "integration" and people, but he treats cultural differences in dichotomous, Huntingtonian terms declaring "We are definitely in the midst of the clash of civilization (the Christian West versus radical Islam)," but with an acknowledgment that there are other conflicts within each "civilization". Ibid, 4. The book is a hodgepodge of subtle/insightful and superficial/reductionist analysis. It is debatable whether the book is more insightful or inflammatory.

35 Ibid, 55 .

36 Wendy Pearlman, "Culture or Bureaucracy? Challenges in Syrian refugees' initial settlement in Germany," Middle East Law and Governance 9, no. 3 (2017): pp. 313-327.

37 Lisa Wedeen, "Ethnography as Interpretive Enterprise," in Political Ethnography: What Immersion Contributes to the Study of Power, ed. Edward Schatz (Chicago: University of Chicago Press 2009), 80-82. Also see Lisa Wedeen, "Conceptualizing Culture: Possibilities for Political Science," The American Political Science Review 96, no. 4 (2002): 713-28.

38 Žižek constructs an oversimplified and dangerous ontological narrative about culture[s], wherein violence prevailed in many countries in the "developing world" as "a permanent 
the norm and not the exception in the nation-state system as stateless refugees and asylees blur the artificial national boundaries and destabilize "time-honored and necessary distinction between nationals and foreigners. ${ }^{39 "}$ Similarly, Zygmunt Bauman refers to refugees and immigrants as the "embodiments of the collapse of order," which accounts, in part, for the rising xenophobic and racist attacks on refugees. Such attacks emboldened jingoistic leaders and movements in Europe and the United States and diverted the anger of the emergent 'precariat' in Western countries and their "humiliating sense of existential uncertainty" and the "incapacity to resist the disabling precariousness" of their own place in the world. ${ }^{40}$

Therefore, unsurprisingly dominant media coverage and political discourse, particularly in the United States, shifted dramatically to demonize refugees and tout their potential as a grave security threat to the West. This discourse was clear when, less than two months before the U.s. presidential election, Donald Trump Jr. tweeted an image comparing Syria refugees to a popular candy, implying there were dangerous terrorists gaining entry into the United States as refugees.

Less than a year before Trump Jr's tweet, the governors of 31 states (30 Republicans and 1 Democrat), issued statements saying they would bar Syrian refugees from settling in their states due to security concerns fueled by ISIS attacks in Paris. ${ }^{41}$ While the governors' statements were polemical rather than legal - as the federal refugee program officials formally rejected their statements ${ }^{42}$ - they contributed to normalizing xenophobic and anti-refugee rhetoric. Following the election of President Donald Trump on November 8, 2016 refugees and asylees in the United States experienced tremendous fear of discrimination and deportation.

Their fear was materialized when anti-refugees discourse, which explicitly targeted Syrians and Muslims, was framed as a securitized discourse. On January

fact of life" (4). In other words, violence is always "out there" in the "other" land, thus Žižek saw in the Paris Attack an example of a symbolic attack on the everyday Western culture, which leaves out the fact the almost all perpetrators of the "terrorist" attacks in France, Belgium, and Britain were born and raised in these countries. Ibid, 4.

39 Arendt, Ibid, 286.

40 Zygmunt Bauman, Strangers at Our Door. (Cambridge, UK: Polity Press, 2016), 15-17.

41 Ashley Fantz and Ben Brumfield, "More than half the nation's governors say Syrian refugees not welcome," $C N N$, November 19, 2015, http://www.cnn.com/2015/11/16/world/ paris-attacks-syrian-refugees-backlash/.

42 Robert Carey, "Resettlement of Syrian Refugees, Dear Colleague Letter 16-02," Office of Refugee Resettlement, November 25, 2015, http://www.acf.hhs.gov/orr/resource/ resettlement-of-syrian-refugees. 
27, 2017, President Trump issued an executive order, titled Protecting the Nation from Foreign Terrorist Entry into the United States, which barred the entry of nationals of seven Muslim-majority countries for at least 90 days; suspended entry of Syrian refugees indefinitely; and stopped the admission of all refugees to the United States for four months. ${ }^{43}$ The Travel Ban or the informally known as the "Muslim Ban" caused chaos and confusion in several airports. Protesters and human rights organizations occupied us airports and plaintiffs challenged the Executive Order. On February 3, the Executive Order was eventually blocked when U.s. District Judge James L. Robart issued a ruling temporarily blocking its enforcement, followed by the decision of the Department of Homeland Security to stop enforcing the Executive Order. ${ }^{44}$

Following the failed attempt to inforce Executive Order 13769, President Trump issued a new Executive Order 13780, on March 6, 2017 to replace the previous one. The new order, which excluded Iraq, was also challenged and blocked by federal courts until June 26, 2017, when the Supreme Court decided to partially lift the halt and that it will hear oral arguments in October. ${ }^{45}$

Based on my interviews and my own experience, ${ }^{46}$ Syrian refugees and asylees in the United States have been feeling increasingly insecure and in a defensive position. Salma (a Syria asylee in her late 20s) reflected on her experience:

When the first travel ban was enforced in January [2017] I spent the first two days crying. Since then we [she and her spouse in Iraq] do not know what to do. I came to the Us from Erbil [Capital of Iraqi Kurdistan] in

43 Exec. Order No. 13769, 3 C.F.R. 8977-8982 (2017). https://www.federalregister.gov/ documents/2017/02/01/2017-02281/protecting-the-nation-from-foreign-terrorist-entry -into-the-united-states.

44 Nicholas Kulish, Caitlin Dickerson and Charlie Savage, "Court Temporarily Blocks Trump's Travel Ban, and Airlines Are Told to Allow Passengers," The New York Times, February 3, 2017, https://www.nytimes.com/2017/02/03/us/visa-ban-legal-challenge.html.

45 Robert Barnes and Matt Zapotosky, "Supreme Court allows limited version of Trump's travel ban to take effect and will consider case in fall," The Washington Post, June 26, 2017, https://www.washingtonpost.com/politics/courts_law/supreme-court-allows-limited -version-of-trumps-travel-ban-to-take-effect-will-consider-case-in-fall/2017/o6/26/ 97afa314-573e-11e7-b38e-35fd8eoc288f_story.html.

46 On January 29, 2017, my brother, an admitted Syrian refugee, was banned from boarding his flight from Istanbul to LAx. He was arrived to the Us through Logan Airport on February 4. For a detailed account see, Emily Cutts, "UMass student returns to joyful embrace UMass student returns," The Daily Hampshire Gazette, February 5, 2017, http://www .gazettenet.com/Logan-Student-7911253. 
September 2015. I sought asylum in June 2016 after the birth of my child here in the Us in January 2016. My case is still pending and my spouse did not see his son yet. We thought the whole process gonna take a couple of years, as many people whom we know told us, and we did not have many options anyway. But now after the travel ban and the new restrictions on Syrians, I am not sure anymore. They might deny my spouse's application after waiting for five or seven years, assuming I will get the interview and my application will be approved. I considered going back to Kurdistan, but I cannot. No country is issuing visas for Syrians. Each time they revoke a travel ban, they come up with a new ban and more difficult rules. I wanted to apply for graduate schools but I asked myself "what if they forced me to leave after six months? why should I apply?" I am totally lost and we have no place to go. ${ }^{47}$

With no sense of future, refugees and asylees will keep swinging between the two poles of humiliation ${ }^{48}$ and will continue their struggle to construct a sense of home.

\section{Conclusion}

Humiliation, dignity, fear, sense of loss, sense of betrayal, insecurity, alienation, dislocation and inability to mourn are crucial to the identity-formation and meaning-making processes of refugees, and they pose methodological challenges and can only be partially represented by quantified data. Such challenges must be reckoned with by researchers who seek to gain in-depth insights into processes of resettlement and integration in hosting countries on the one hand; and how to approach post-conflict reconstruction planning concerning Syrian social fabric on the other. The ethnographic-interpretive approach, which is attentive to empathetic understanding of the participants' meanings and actions and the ethics of power, provides an invaluable method available for social scientists and policy-makers to better understanding the complexity and dynamism of the social and political worlds. With its sensitivity to the intersubjective character of meanings of social realities, such an approach will expand the possibilities for adopting more adequate policies which address the particularity of the refugees' experiences in different contexts and how they themselves perceive and respond to these policies.

47 Interview with Salma, Massachusetts, USA, July 17, 2017.

48 Mollica, ibid, 79-81. 